That the outbrcak was of an overwhelming description may be seen from the following table, quoted from the same source:-

"In I house there were

$$
\text { Deaths. }
$$

In each of 3 others $\quad \ldots \quad r \quad 8=12$

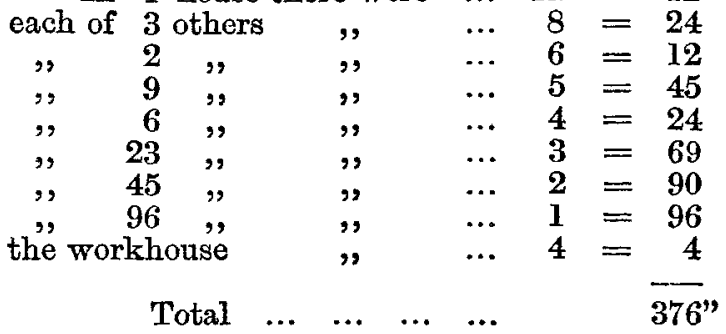

Now to show the effect of age as influencing the mortality :Of 376 deaths, 24 were between the ages of 10 and 20 , or 1 in 15 군.

The 24 deaths in the second decade are thus distributed:Aged 11 years 5 deaths

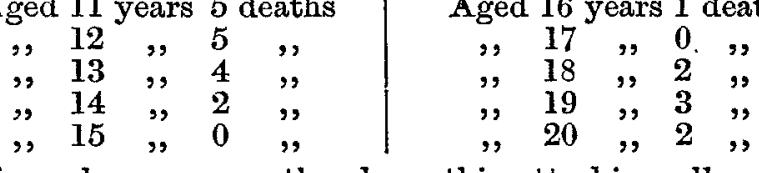

If, in such a severe outbreak as this attacking all ages in discriminately, the mortality was 1 in $15 \frac{1}{2}$, in the second decade of deaths at all ages, then it is not extraordinary that, with less severe cases, there should have been but 1 in 14 .

The mortality, as far as the observation of the 376 cases goes, with reference to age, may be thus stated:-

Outbreak in Berwick-street.

10 and under ... 1 in 5

10 to $20 \quad \ldots \quad \ldots \quad 1-15$

$20-30 \quad \ldots \quad \ldots \quad 1-8$

$40-50 \quad \cdots \quad \cdots \quad 1-7 \frac{1}{4}$

Result of Cases Treated in King's College.

$$
\text { ... } 1 \text { in } 4 \frac{2}{3}
$$$$
\text { ... } \quad \ldots 1-14
$$$$
\text { ... } \quad 1-3 \frac{1}{9}
$$$$
\cdots \quad \cdots \quad 1-4 \frac{2}{3}
$$

To illustrate still more fully the influence of age upon the results as to mortality, the following are the total number of cases which occurred in the workhouse of St. James's, West. minster, during the epidemic of $1854:-$

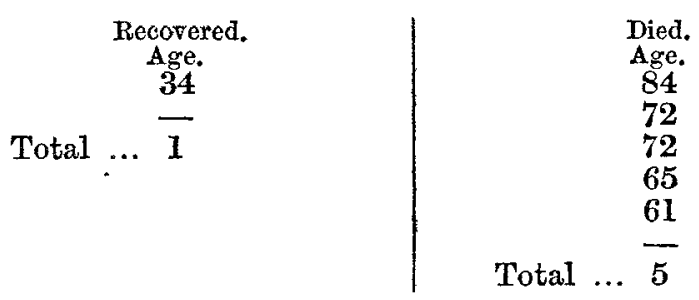

Cases admitted into the Cholera Hospital of St. James's, Westminster, 1854:-

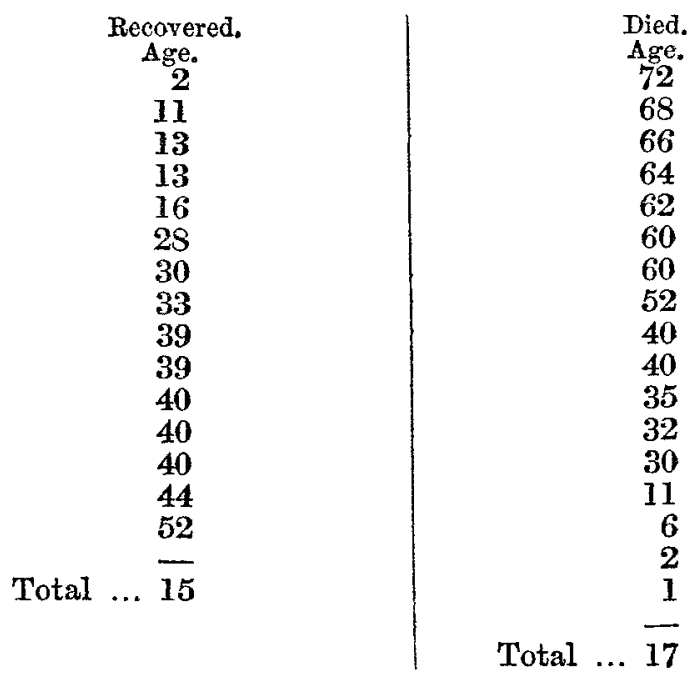

Before analyzing this table into decades, and to express the subject under consideration clearly, let us suppose, for the sake of argument, that the 38 cases treated in King's College Hospital had all been above 60 years of age, then, if all had died, as far as the results are concerned, it would have been no argument against any treatment adopted, for all in the

* No case whatever recorered at King's College above forty; the only three cases above that age died. several tables died above that age. So, also, if all the 38 cases had happened to have been of the ages of from 15 to 17 inclusive, then, if all had recovered, that result would have proved nothing conclusive in favour of the plan of treatment, for if but one patient died at that period of life out of 376 cases of the most virulent kind known in this country, then one out of 38 would have been a large proportion. But in order to compare the table fairly with that of King's College, let us throw out the cases above $\mathbf{5 0}$ years of age, a class with which King's College had nothing to do, and also those between the ages of 10 and 20 , from both tables, a class in which the expectation of death is but 1 in 15 in the severest form. The result stands thus:-

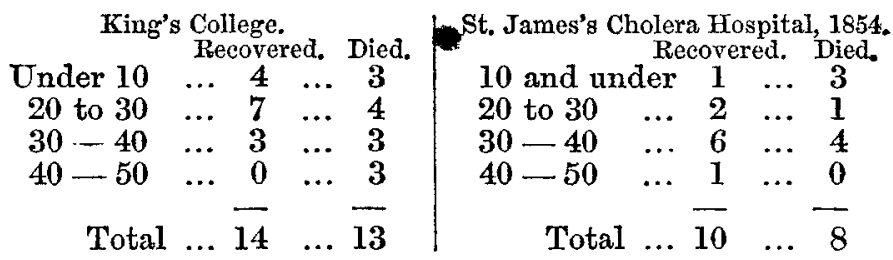

Lord Brougham, in his "Introduction to the Study of Natural Theology," says, (p. 188:) "Thus, when the physiologist has discovered some part of the animal body before unknown, or observed some new operation of the known organs, he never doubts that design exists, and that some end is to be answered. This he takes for granted, without any reasoning, and he only intends to find out what the purpose is-what use the part can have-what end the operation is intended to accomplish,-never supposing it possible, that either the part could be created, or the function appointed, without an object. The investigation, conducted on the assumption of this postulate, has frequently led to the most brilliant dis. coveries, amongst others, to by far the most important ever made in physiological science.'

The philosophy which pervades Dr. G. Johnson's book is not of this kind, and on the subject of castor oil, it appears to be more like that species of philosophy of which Morison the hygeist is the arch expounder. The Materia Medica is as widely open to the physician for the treatment of cholera as to the surgeon for the treatment of mechanical injury; but it is only safe in the hands of those practitioners who clearly comprehend the principles on which disease is remedied, or injury is repaired.

Great Marlborough-street, July, 1855.

\section{SECOND QUARTERLY METEOROLOGICAL REPORT FOR ST. THOMAS'S HOSPITAL} FOR 1855 .

By ROBERT DUNDAS THOMSON, M.D., F.R.S. L. \& E. PROFESSOR OF CHEMISTRX IN ST. THOMAS'S HOSPXTAL COLLEGE.

THE temperature of the quarter has fallen below that of a mean of many years, and has been very much in deficiency of that of last year. In April the mean heat was only $3^{\circ}$ below the average of sixty-five years, but it was $3^{\circ} \cdot 1$ colder than April, 1854. May was $2^{\circ} \cdot 1$ colder than the corresponding month of last year, and June $8^{\circ}$ warmer than the same month of 1854. But May of this year was $3^{\circ} \cdot 5$ and June $1^{\circ} \cdot 3$ colder than the average. The warmest days in April, May, and June were the $16 \mathrm{th}, 26 \mathrm{th}$ and $6 \mathrm{th}$, when the thermometer stood at $68^{\circ} \cdot 4,80^{\circ} \cdot 5$, and $85^{\circ} \cdot 1$; the coldest days marking respectively in these months, $26^{\circ} \cdot 9,33^{\circ} \cdot 3$, and $42^{\circ} \cdot 7$. The hottest days in the same months in 1854 giving $74^{\circ} \cdot 7,70^{\circ}$, and $79^{\circ} \cdot 4$; and the coldest, $32^{\circ} \cdot 6,38^{\circ}$, and $44^{\circ} \cdot 4$. The barometric pressure during the last half of April was high, the mercurial column never falling below 30 inches. It continued high in the beginning of May, fell towards the middle, and continued under 30 inches to the end of the month. Considerable variation in the pressure characterized the first half of June, when the barometer rose during the last half, and remained above 30 inches. The amount of rain has been small during the quarter: -2 ineh in April, $1 \cdot 27$ inch in May, and $1 \cdot 11$ inches in June. This is attributable to the preponderance of northerly and easterly winds, which must be viewed as evaporating rather than as condensing currents of air, and as depressors of heat. The lilac only came into flower on the 23rd of May, and agriculturists consider the year as a month behind the average. The effect has been equivalent to transferring London to a latitude $7^{\circ}$ to the north. The oxidizing condition of the air, as indicated 
April, 1855. - 30 Days.

\begin{tabular}{|c|c|c|c|c|c|c|c|c|c|c|c|c|c|}
\hline \multirow[b]{2}{*}{ Week ending - } & \multirow{2}{*}{$\begin{array}{c}\text { Barometer. } \\
\text { Corrected } \\
\text { Mean. }\end{array}$} & \multicolumn{4}{|c|}{ Thermometers. } & \multirow{2}{*}{$\begin{array}{c}\text { Adopted } \\
\text { Temperature } \\
\text { of Air. }\end{array}$} & \multirow{2}{*}{$\begin{array}{c}\text { Adopted } \\
\text { Temperature } \\
\text { of } \\
\text { Evaporation. }\end{array}$} & \multirow{2}{*}{$\begin{array}{l}\text { Dew } \\
\text { Point. }\end{array}$} & \multirow{2}{*}{$\begin{array}{l}\text { Elastic } \\
\text { Force of } \\
\text { Vapour. }\end{array}$} & \multirow{2}{*}{$\begin{array}{l}\text { Weight of } \\
\text { Vapour } \\
\text { in Cubie } \\
\text { Foot of Air. }\end{array}$} & \multirow{2}{*}{ Wind. } & \multicolumn{2}{|l|}{ RAIS. } \\
\hline & & Dry. & Wet. & Highest & Lowest & & & & & & & Amount & \\
\hline Saturday, 7th ... & $\begin{array}{l}\text { Inches. } \\
\mathbf{3 0} \cdot 045\end{array}$ & $\stackrel{\circ}{46 \cdot 2}$ & $4 i \cdot 5$ & $51 \cdot 0$ & $\stackrel{\circ}{37} \cdot 0$ & $\stackrel{\circ}{44} \cdot 9$ & $\stackrel{\circ}{40 \cdot 2}$ & $\stackrel{\circ}{34} \cdot 5$ & \begin{tabular}{|c|} 
Inches. \\
-222
\end{tabular} & $\begin{array}{c}\text { Grains. } \\
2 \cdot 56\end{array}$ & Variable. & $\begin{array}{c}\text { Inches. } \\
\cdot 10\end{array}$ & $\mathbf{2}$ \\
\hline 14th ... & $29 \cdot 677$ & $51 \cdot 1$ & $45 \cdot 4$ & $56 \cdot 4$ & $44 \cdot 2$ & $50 \cdot 5$ & $44 \cdot 8$ & $38 \cdot 6$ & $\cdot 256$ & $2 \cdot 92$ & N.W. & $\cdot 10$ & 2 \\
\hline 21 st ... & $30 \cdot 290$ & $55 \cdot 4$ & $47 \cdot 3$ & $62 \cdot 2$ & $43 \cdot 6$ & $53 \cdot 6$ & $45 \cdot 5$ & $36 \cdot 9$ & $\cdot 241$ & $2 \cdot 74$ & Variable. & ... & \\
\hline 28th ... & $30 \cdot 302$ & $49 \cdot 6$ & $43 \cdot 4$ & $55 \cdot 3$ & $38 \cdot 9$ & $48 \cdot 1$ & $41 \cdot 9$ & $34 \cdot 8$ & -224 & $2 \cdot 59$ & Variable. & $\cdots$ & $\mathbf{0}$ \\
\hline $\left.\begin{array}{c}\text { Monthly Mean, } \\
\text { from lstto30th, } \\
\text { inclusive. }\end{array}\right\}$ & $30 \cdot 084$ & $46 \cdot 3$ & $41 \cdot 6$ & $56 \cdot 1$ & $41 \cdot 0$ & $46^{\circ} 6$ & $41 \cdot 9$ & $34 \cdot 8$ & $\cdot 238$ & 74 & N.W. & 2 & $\mathbf{3}$ \\
\hline $\begin{array}{l}\text { Highest rea } \\
\text { Lowest rea }\end{array}$ & ing 0 & aete & a 10 & $\cdots$ & $\begin{array}{l}\cdots \\
\cdots\end{array}$ & $\begin{array}{l}0.9 \\
48\end{array}$ & ब1не & in & $m$ ther & rmol & $\begin{array}{l}\text { on 17th } \\
\text { on lst }\end{array}$ & $\begin{array}{l}68^{\circ} \cdot 4 \\
26^{\circ} \cdot 9\end{array}$ & \\
\hline & onthly $\mathrm{r}$ & $\cdots$ & $\cdots$ & ... & $\ldots$ & 55 & Ra1 & e of $t$ & mperatu & are in mon & $\ldots$ & $41^{\circ} \cdot 5$ & \\
\hline
\end{tabular}

\section{May, 1855.-31 Days.}

\begin{tabular}{|c|c|c|c|c|c|c|c|c|c|c|c|c|c|}
\hline \multirow{2}{*}{ Week ending- } & \multirow{2}{*}{$\begin{array}{c}\text { Barometer. } \\
\text { Corrected } \\
\text { Mean. }\end{array}$} & \multicolumn{4}{|c|}{ THERMoNorTERS. } & \multirow{2}{*}{$\begin{array}{l}\text { Adopted } \\
\text { Temperature } \\
\text { of Air. }\end{array}$} & \multirow{2}{*}{$\begin{array}{l}\text { Adopted } \\
\text { Temperature } \\
\text { of } \\
\text { Evaporation. }\end{array}$} & \multirow{2}{*}{$\begin{array}{l}\text { Dew } \\
\text { Point. }\end{array}$} & \multirow{2}{*}{$\begin{array}{l}\text { Elastic } \\
\text { Force o } \\
\text { Vapour. }\end{array}$} & \multirow{2}{*}{$\begin{array}{l}\text { Weight of } \\
\text { Vapour } \\
\text { in Cubie } \\
\text { Foot of Air. }\end{array}$} & \multirow{2}{*}{ Wind. } & \multicolumn{2}{|l|}{ Runr. } \\
\hline & & Dry. & wet. & Highest & Lowest & & & & & & & Amount & 第 \\
\hline Saturday, 5th ... & $\begin{array}{l}\text { Inches. } \\
\mathbf{3 0} \cdot 083\end{array}$ & $\stackrel{\circ}{48} \cdot 6$ & $\stackrel{\circ}{43} \cdot 0$ & $55 \cdot 4$ & $38 \cdot 8$ & $\stackrel{\circ}{47 \cdot 6}$ & $4 \dot{2} \cdot 0$ & $\stackrel{\circ}{35 \cdot 2}$ & $\begin{array}{c}\text { Inches. } \\
\cdot 229\end{array}$ & $\begin{array}{l}\text { Grains. } \\
\mathbf{2} \cdot 64\end{array}$ & N.E. & $\begin{array}{c}\text { Inches. } \\
.01\end{array}$ & 1 \\
\hline $12 \operatorname{th} \ldots$ & $29 \cdot 784$ & $53 \cdot 8$ & $46 \cdot 5$ & $60 \cdot 3$ & $43 \cdot 2$ & $52 \cdot 5$ & $45 \cdot 2$ & $36 \cdot 9$ & $\cdot 242$ & $2 \cdot 76$ & W. & .55 & 4 \\
\hline 19 th ... & $29 \cdot 804$ & $50 \cdot 4$ & $44 \cdot 6$ & $54 \cdot 2$ & $42 \cdot 7$ & $49 \cdot 2$ & $43 \cdot 4$ & $36 \cdot 7$ & $\cdot 241$ & $2 \cdot 77$ & Variable. & $\cdot 3$ & 2 \\
\hline 26 th ... & $29 \cdot 847$ & $61 \cdot 4$ & $52 \cdot 7$ & $66 \cdot 2$ & $49 \cdot 0$ & $59 \cdot 3$ & $51 \cdot 6$ & $45 \cdot 5$ & $\cdot 327$ & $3 \cdot 67$ & Variable. & $\cdots$ & 0 \\
\hline $\left.\begin{array}{c}\text { Monthly Mean, } \\
\text { from Ist to 31st, } \\
\text { inclusive. }\end{array}\right\}$ & $29 \cdot 831$ & $49 \cdot 7$ & $44 \cdot 5$ & $59 \cdot 9$ & $44 \cdot 4$ & $50 \cdot 0$ & $44 \cdot 8$ & $37 \cdot 6$ & -264 & $3 \cdot 03$ & N.E. & $1 \cdot 27$ & $\mathbf{s}$ \\
\hline \multicolumn{4}{|c|}{$\begin{array}{l}\text { Highest reading of barometer on } 1 \text { st } \ldots \\
\text { Lowest reading of barometer on } 11 \text { th... }\end{array}$} & $\begin{array}{ll}. & \cdots \\
\cdots\end{array}$ & \multicolumn{3}{|c|}{$\begin{array}{l}\text { Inches. } \\
30 \cdot 256\end{array}$} & maxim & $\begin{array}{l}\operatorname{lum} \text { the } \\
\text { um ther }\end{array}$ & rmomet & $\begin{array}{l}\text { on } 27 \text { th } \\
\text { n. } 3 \text { rd }\end{array}$ & \multicolumn{2}{|c|}{$\begin{array}{l}80^{\circ} \cdot 5 \\
33^{\circ} \cdot \mathbf{3}\end{array}$} \\
\hline $\mathbf{M}$ & thly ra & ... & ... & ... & $\ldots$ & $\cdot 850$ & & of & manot & $x$ & ... & $\ldots \quad 47^{\circ} \cdot 2$ & \\
\hline
\end{tabular}

\section{June, 1855.-30 Days.}

\begin{tabular}{|c|c|c|c|c|c|c|c|c|c|c|c|c|c|}
\hline \multirow[b]{2}{*}{ Week ending- } & \multirow{2}{*}{$\begin{array}{l}\text { Barometer. } \\
\text { Corrected } \\
\text { Mean. }\end{array}$} & \multicolumn{4}{|c|}{ THERKOMETERS. } & \multirow{2}{*}{$\begin{array}{c}\text { Adopted } \\
\text { Temperature } \\
\text { of Air. }\end{array}$} & \multirow{2}{*}{$\begin{array}{c}\text { Adopted } \\
\text { Temperature } \\
\text { of } \\
\text { Evaporation. }\end{array}$} & \multirow{2}{*}{$\begin{array}{l}\text { Dew } \\
\text { Point. }\end{array}$} & \multirow{2}{*}{$\begin{array}{l}\text { Elastic } \\
\text { Foree of } \\
\text { Vapour. }\end{array}$} & \multirow{2}{*}{$\begin{array}{c}\text { Weight of } \\
\text { Vapour } \\
\text { in Cubie } \\
\text { Foot of Air. }\end{array}$} & \multirow{2}{*}{ Wind. } & \multicolumn{2}{|c|}{ RAIN. } \\
\hline & & Dry. & Wet. & Highest & Lowest & & & & & & & Amount & 苇 \\
\hline Saturday, 2nd ... & $\begin{array}{l}\text { Inches. } \\
29 \cdot 830\end{array}$ & $\stackrel{0}{52 \cdot 3}$ & $\dot{48} \cdot 7$ & $\stackrel{\circ}{59 \cdot 9}$ & $46 \cdot 8$ & $\dot{52} \cdot 6$ & $\stackrel{\circ}{49} \cdot 0$ & $\stackrel{\circ}{44} \cdot 8$ & $\begin{array}{c}\text { Inches. } \\
\cdot 319\end{array}$ & $\begin{array}{c}\text { Grains. } \\
3 \cdot 64\end{array}$ & N.E. & $\begin{array}{c}\text { Inches. } \\
-83\end{array}$ & \\
\hline $9 \operatorname{th} \ldots$ & $29 \cdot 909$ & $63 \cdot 9$ & $56 \cdot 6$ & $71 \cdot 3$ & $53 \cdot 7$ & $62 \cdot 5$ & $55 \cdot 2$ & $49 \cdot 3$ & $\cdot 370$ & $4 \cdot 15$ & S.W. & $\cdot 05$ & \\
\hline 16 th ... & $29 \cdot 756$ & $60 \cdot 1$ & $54: 5$ & $67 \cdot 5$ & $52 \cdot 0$ & $59 \cdot 7$ & $54 \cdot 1$ & $49 \cdot 6$ & $\cdot 374$ & $4 \cdot 20$ & Variable. & $\cdot 6$ & \\
\hline 23rd ... & $30 \cdot 148$ & $58 \cdot 5$ & $51 \cdot 2$ & $62 \cdot 6$ & $49 \cdot I$ & $56 \cdot 9$ & $49 \cdot 6$ & $44 \cdot 5$ & $\cdot 313$ & $3 \cdot 51$ & \multirow{2}{*}{$\begin{array}{c}\text { N. } \\
\text { Variable. }\end{array}$} & $\cdot 04$ & \\
\hline 30 th ... & $30 \cdot 179$ & $69 \cdot 2$ & $60 \cdot 2$ & $72 \cdot 0$ & $56 \cdot 9$ & $66 \cdot 6$ & $57 \cdot 6$ & $51 \cdot 6$ & -400 & $4 \cdot 44$ & & $\cdots$ & \\
\hline $\left.\begin{array}{l}\text { Monthly Mean, } \\
\text { from lstto } 30 \mathrm{th}, \\
\text { inclusive. }\end{array}\right\}$ & $29 \cdot 985$ & $57 \cdot 7$ & $52 \cdot 3$ & $65 \cdot 7$ & $52 \cdot 3$ & $57 \cdot 4$ & $52 \cdot 0$ & $46 \cdot 4$ & $\cdot 351$ & $3 \cdot 96$ & S.W. & $1 \cdot 11$ & \\
\hline \multicolumn{4}{|c|}{$\begin{array}{l}\text { Highest reading of barometer on } 20 \text { th } \\
\text { Lowest reading of barometer on } 15 \text { th }\end{array}$} & $\begin{array}{ll}1 & \cdots \\
1 & \cdots\end{array}$ & $\begin{array}{ll} & \ln c \\
\ldots & 30\end{array}$ & \multicolumn{6}{|c|}{$\begin{array}{l}\text { Highest reading of maximum thermometer on } 7 \mathrm{th} \\
\text { Lowest reading of minimum thermometer on 1st }\end{array}$} & $\begin{array}{l}85^{\circ} \cdot 1 \\
42^{\circ} \cdot 7\end{array}$ & \\
\hline \multicolumn{3}{|c|}{ Monthly range } & $\ldots \quad .$. & . $\ldots$ & $\ldots$ & .076 & \multicolumn{5}{|c|}{ Range of temperature in month ... } & $42^{\circ} \cdot 4$ & \\
\hline
\end{tabular}

Quarterly Summary.

\begin{tabular}{|c|c|c|c|c|c|c|c|c|c|c|c|}
\hline \multirow{2}{*}{$\begin{array}{l}\text { Barometer, } \\
\text { Corrected } \\
\text { Mean. }\end{array}$} & \multicolumn{4}{|c|}{ THERMOMETERS. } & \multirow{2}{*}{$\begin{array}{c}\text { Adopted } \\
\text { Temperature } \\
\text { of Air. }\end{array}$} & \multirow{2}{*}{$\begin{array}{c}\text { Adopted } \\
\text { Temperature } \\
\text { of } \\
\text { Evaporation. }\end{array}$} & \multirow{2}{*}{$\begin{array}{l}\text { Dew } \\
\text { Point. }\end{array}$} & \multirow{2}{*}{$\begin{array}{l}\text { Elastic } \\
\text { Force of } \\
\text { Vapour. }\end{array}$} & \multirow{2}{*}{$\begin{array}{l}\text { Weight of } \\
\text { Vapour } \\
\text { in Cubic } \\
\text { Foot of Air. }\end{array}$} & \multirow{2}{*}{ Wind. } & \multirow{2}{*}{$\frac{\text { RArN. }}{\text { Amount }}$} \\
\hline & Dry. & wet. & Highest & Lowest. & & & & & & & \\
\hline $\begin{array}{l}\text { Inches, } \\
29 \cdot 967\end{array}$ & $51 \cdot 2$ & $46^{\circ} \cdot 1$ & $60 \cdot 6$ & $4 \check{5} \cdot 9$ & $\stackrel{\circ}{51 \cdot 3}$ & 40 & $3 \dot{9} \cdot 6$ & $\begin{array}{c}\text { Inches. } \\
\cdot 284\end{array}$ & $\begin{array}{c}\text { Grains. } \\
3 \cdot 24\end{array}$ & $\begin{array}{l}\text { N.E.,S.W. W. } \\
\text { N.W. }\end{array}$ & \begin{tabular}{|c|} 
Inches. \\
2.58
\end{tabular} \\
\hline
\end{tabular}


by our present imperfect methods, during May and June has been distinct, with few exceptions, but the amount has not been great, the maximum ozone having only been $2^{\circ} \cdot 5$, and that merely on one occasion. So soon as such a stagnancy of the air occurs as to be accompanied with a deficiency in its oxiclating power, practitioners should be on the watch for the occurrence of diarrhoea and cholera, if we are to reason from the characteristic phenomena last year; but as yet there has been no such symptom in the atmosphere.

\section{9. altinuto}

OF THE PRACTICE OF

\section{MEDICINE AND SURGERY IN THE}

\section{HOSPITALS OF LONDON.}

Nulla est alia pro certo noscendi via, nisi quam plurimas et morborum et dissectionum historias, tam aliorum proprias, collectas habere et in
secomparare, MIorgAGN. De Sed. et Cuus. MIorb. lib. 14. Promium.

\section{ROYAL FREE HOSPITAL.}

RUPTURE OF THE LIGAMENTUM PATELEA; RECOVERY.

\section{(Under the care of Mr. T. WAKLEX.)}

Ruptuke of ligaments, more particularly rupture of the ligamentum patellæ, as stated by $\mathrm{Mr}$. T. Wakley a few days ago, is very seldom met with in nosocomial practice; so that the case to which we wish to.day to draw attention is one of those which will repay attention, and be perused with interest. The variety of cases at the different hospitals, it is sometimes objected, are without connexion, but every original or new case must be separated from those which went before, and the highest reward of hospital industry is found in meeting every emergency as it arises.

"Ligaments are the last of all the different parts of the body to be diseased," according to the acute observation of Wickham, " and it is very common to find the ligaments perfect when every other texture is either altered or destroyed ;" and we learn also that the synovial membrane passing sometimes over ligaments, and reflected from the inside of capsules and joints, is more highly oroanized than the so-called membrane over the surface of the cartilages of the articulation itself. All writers on surgery, as Mr. Wakley observed in the present case, demonstrate these facts, as well as the force of muscular action, by the fracture of bones, and more especially by fracture of the patella. In the works of Desault, Petit, Sir Astley Cooper, for instance, we read of numerous examples; but the instances of rupture, or tearing across of the ligament of the patella itself, are very rarely met with indeed, and form by far the exception to a general rule. Desanlt tells us of a soldier who broke his patella by the mere muscular effort of stretching out his foot to kick his sergeant! At the Hôtel Dieu, in operating for calculus in the bladder, it was found in one case that in the kicking of the patient, and spasms of the muscles, both patellæ had got broken across during the operation. While more recently still, within the past twelve months, we have heard Mr. Stanley demonstrate to his class some very singular instances of ligaments being torn from their attachments rather than break across. This action cf "spasm," or of muscular contraction acting on ligaments, as a cause of fracture or dislocation, Mr. Stanley is inclined to consider as too often forgotten or lost sight of. $\mathrm{He}$ has known fracture to oceur in the violent paroxysms of epilepsy; even in the spasms of cholera the ligaments may be torn! Mr. Stanley, from his old recollections, and notes of cases he has known in the practice of Mr. Abernethy or Mr. Lawrence through a series of years, constantly cites in his clinical observations some most striking and apposite cases of tearing out of ligaments or rupture of tendons, all more or less explanatory of Mr. Wakley's case. Thus, a man was brought into St. Bartholomew's Hospital, not with dislocation, but fracture of the leg in two places, the leg being broken by the crush or snap of the ligaments or tendons, caused by kicking at his adversary. In another instance, a bookbinder at work in a room where a large fly-wheel was revolving, happened one day to tie a piece of string round his thumb to remind him of something when he got home. One end of the string, $\mathrm{Mr}$.
Stanley says, got suddenly into the machinery. With the rapidity of thought he attempted to withdraw his arm, but found his thumb gone, and his arm broken in two places, not by direct violence, but by the spasm or drag of the ligaments and tendons. The flexor pollicis longus tendon, which is now pre serred in the museum, was completely drawn out from its origin in the interosseous ligament; the humerus was broken at the deltoid insertion, and the radius and ulna were both twisted by the ligaments. Numerous other instances, such as rupture of the internal lateral ligament of the ankle by a violent twist of the foot outwards, preceding the fracture of the bone, might also be adduced.

According to some recent microscopic examinations of torn ligaments, it appears that inflamed ligaments from rupture are generally found thickened and more pulpy than in their normal condition; thus, perhaps, offering a sort of predisposition to be torn, in preference to the bones being dislocated or fractured.

A very interesting case is given by Sir Astley Cooper, where a patella which had been previously broken, and had united in the usual mode, was found opened up again in after years by accidental ulceration; and by the destruction of the not very highly vitalized parts which had formed the line of ligamentous union. All such cases are different from that under the care of Mr. T. Wakley, to which we wish to draw attention at present. Yet, as was observed by this surgeon, all such injuries reflect more or less light on the obscure diseases of the ligaments of the knee-joint; enlarged on, in their more purely pathological bearings, by Sir B. Brodie, Mr. Coulson, Mr. Stanley, and other writers. The ligamentum patella also forms such an essential or integral portion of the knee-joint itself, that no surgical injury of this part can be treated without due care and precaution. The areolar stissue of the substance of such ligaments, it is further said, under such an accident as the present, becomes highly vascular, often leading to subsequent softening or ulceration, and is very slow in healing by first intention like other parts. This is well shown in a case now under Mr. Stanley and Mr. Paget, where the tendons of the wrist were cut across, and where all the various appliances of gutta percha, leather, \&c., have been nearly exhausted in keeping the parts in apposition.

The serious character of surgical injury of the ligamentum patellæ, if not properly diagnosed, or recognised at first through the odematous swelling and discoloration about the knee, may also be learned from a case cited by Sir Charles Bell, where the substance forming the ligamentous union was so incorporated with the skin, that the latter happening to be lacerated, the entire knee-joint was laid open, and amputation of the thigh became necessary. In this point of view, no case of ruptured ligament, however insignificant in hospital practice it may appear to be, is unworthy of study and attention.

We are indebted to Mr. Turtle, the senior house-surgeon, for the following history of the case:-

John T_- cabman, aged forty-two, was admitted into the accident ward, under the care of Mr. T. Wakley, with rupture of the ligamentum patellæ of the right leg. He is a robust and remarkably healthy-looking man, and has generally enjoyed good health. He says that he was in the act of getting up to the driving-seat of his cab, and had placed his left leg on the wheel, and was raising the other, when he felt something give way at the knee, with a loud report, and felt as thongh a "tight piece of cord had been cut through," after which he was unable to put the right leg to the ground, and a great deal of swelling took place around the joint. The accident occurred at a quarter-past nine A.M., and he was brought to the hospital immediately in a cab. He was seen by the house-surgeon at ten A.M., when the patella was found three inches above its natural position, and a great depression was found imnediately over the joint. A straight splint was applied to the back of thigh and leg, with a cross splint fastened to it behind the knee; the patella was brought into its normal situation by a few turns of a roller from the cross splint. The knee, leg, and foot became enormously swollen, and caused considerable diffi. culty in the after treatment, which consisted of modifications of the above plan. The swelling has subsided, and he can raise his leg unaided. The patella is very nearly in its proper place. A few days since, a bandage of leather, encircling the knee, and provided with lateral and posterior iron rods, was applied, and, aided by this simple but most effectual means, he can support the weight of his body upon the affected leg.

In anatomical language, perhaps, the ligamentum patella is not a ligament at all, but is rather the prolongation of the tendon of the extensor musscles of the thigh, so familiar in pathological specimens, and in the operating theatre, extending down the thigh towards the tubercle of the tibia. 